\title{
The eco-developmental organisational culture in the eco-developmental competitiveness of business enterprises
}

All our knowledge has its origins in our perceptions. Leonardo Da Vinci

\author{
Michat A. LeŚNIEWSKI ${ }^{1}$
}

Jan Kochanowski University in Kielce, Institute of Management

\begin{abstract}
The natural environment is one of the important elements shaping the development of a business enterprise in the ever-changing reality. Each business entity which wants to become a pro-environmental enterprise has to implement properly the essence of the ecodevelopment concept inside its organisation. Organisational culture and competitiveness constitute two significant functional areas of business enterprises. Exposed to the influence of eco-development, these areas adopt the shape of the eco-developmental organisational culture and eco-developmental competitiveness of business enterprises. Both these areas are complementary to each other and together create a coherent system.

The objective of the article is to present the essence and structure of an eco-developmental organisational culture in the eco-developmental competitiveness of business enterprises. It includes the following theses: (i) An eco-developmental organisational culture is shaped by both soft and hard factors; and (ii) The factors of an eco-developmental organisational culture (as a constituent of eco-developmental competitiveness) shape the eco-developmental cultural competitiveness of business enterprises.

The article is based on the results of the author's empirical research (a survey of a sample of 200 Polish business enterprises in the Świętokrzyskie Province) preceded by a thorough study of the literature on the subject.
\end{abstract}

Paper type: research paper

1 michaladam.lesniewski@wp.pl; konkurencyjnosc.com.pl 
Keywords: eco-developmental organisational culture, eco-developmental competitiveness, eco-developmental cultural competitiveness, Model of the Eco-developmental Cultural Competitiveness of Enterprises

\section{Introduction}

The issue of natural environment protection is becoming more and more crucial in various areas of man's activities and his functioning in various organisations, including business enterprises (Jedynak, 2010; Lipińska, 2015). Man's response to positive relationships with the natural environment is eco-development ${ }^{2}$ orienting an organisation (a business enterprise) towards the so-called green growth. If it is to exist in a business enterprise, eco-development has to be included properly in each area of an enterprise's activities. Organisational culture and competitiveness constitute two significant functional areas of business enterprises. If these areas are to be activated in eco-development, they need to adopt a particular form in an enterprise: in the organisational culture area it is an eco-developmental organisational culture, while competitiveness adopts the form of eco-developmental competitiveness.

The objective of this article is to present the essence and structure of an ecodevelopmental organisational culture in the eco-developmental competitiveness of business enterprises. The first thesis reads as follows: An eco-developmental organisational culture is shaped by both soft and hard factors. The second thesis reads as follows: The factors of an eco-developmental organisational culture (as a constituent of eco-developmental competitiveness) shape the eco-developmental cultural competitiveness of business enterprises.

The article is based on the results of the research survey conducted by the author on a sample of 200 Polish business enterprises in the Swiętokrzyskie Province preceded by a thorough study of the literature on the subject.

\section{Eco-development of a business enterprise - an organisation's life in harmony with nature}

The notion of eco-development was formulated in 1975 during the Third Managing Session of the United Nations Environment Programme. The leading idea of societies following the path of eco-development is respect for the values of the natural environment and the shaping of the spatial order in a manner recognising the pri-

2 It is necessary to remember that eco-development is related to ecology, which, however, is not emphasised in this paper. But the understanding of ecology constitutes a strong foundation for the understanding of eco-development. 
ority of ecological requirements over civilisational growth as well as cultural, economic, and social development. Eco-development is an attempt not only to find optimum relationships between man and nature but also to improve the quality of the environment because in consequence of man's conquering and changing nature, it is possible to notice the phenomenon of man's intensifying dependence on nature. Being a synonym of safe social and economic development, this model guarantees survival and further development to the present and future generations by preventing, minimising or completely eliminating changes and damage caused by man's activities. This is a process of growth and changes which fulfils the needs of the present generations without simultaneously depriving the future generations of possibilities of fulfilling their own needs (Pęski, 1999, p. 31). It is defined the most frequently as a particular area's model of development based on the assumptions of natural conditions and the maintenance of ecological balance. In such a situation, technical progress and continually improved technological solutions should exert a considerable influence on not only a region's economic growth but also the improvement of the quality of the environment.

The basic rules of shaping eco-development include the following (Kołodziejski, 1997, pp. 49-50):

- a comprehensive and dynamic approach to natural, social and economic phenomena occurring in a particular area,

- an interactive perception of reality comprising a number of connections and relationships among various forms of using and developing space,

- an analysis of environmental components with respect to the possibility of their performance of various functions,

- an assessment of changes in the environment from the perspective of values, with the possibility of assuring sustainable development as nature's main feature.

Eco-development is sometimes identified with sustainable development (Borys, 1999, p. 69; Czyż, 2000; Kozłowski, 1998; Nowicki \& Ribbe, 2001). Problems with distinguishing between these two notions in the Polish language result from different translations of the term sustainable development, whose Polish translations emphasise either sustainability (i.e. the possibility of continuing development in the long run, which should be understood as "eco-development") or stability of development understood as evenness or uniformity. Recipes for the aforementioned inconsistencies have been proposed, among others, by Kozak, Pyszkowski, and Szewczyk (2001, pp. 10, 46, 56), who have distinguished the following three notions: firstly, sustainable regional development, whose essence is prevention of excessive and "unreasonable" differences among regions as well as pursuit of balance in regional development and optimisation of resource utilisation; secondly, sustainable development, which is social and economic development maintaining the features of permanence in the long term and not being destructive to the environment; and thirdly, eco-development, which is permanent and stable development in harmo- 
ny with nature, capable of survival and self-sustaining, constituting an example of an antidote to the global civilisational crisis and a determinant of shaping the future from the perspective of a distant time horizon. It should be emphasised that distinguishing a few notions does not result in determining clear borders between the discussed categories. On the other hand, considering these terms as equivalent results in excessive generalisations because eco-development, which is the subject matter of the considerations presented in this paper, is included in sustainable development, which is a broader term emphasising, besides ecological factors, also social, economic, and cultural factors.

From the point of view of business enterprises, eco-development means lean manufacturing, utilisation of waste, respect for materials, resources and space, as well as reduction of dependence on non-renewable resources, business activities which do not result in irreversible changes to nature, and analyses of conducted activities from the perspective of their future consequences. Furthermore, eco-development stresses the necessity of reducing the emissions of carbon oxides, sulphur dioxide and nitrogen oxides to the atmosphere as well as other toxic pollutants to the water, air or soil.

The leading thought of the eco-development philosophy is such development that allows the fulfilment of the needs of this generation, but also of the future generations at a similar level that would be satisfactory and socially acceptable. The simplest definition of eco-development reads as follows: eco-development is permanent and sustainable social and economic development which allows the reconciliation of the material aspirations of the present and future generations with the necessity of protecting the natural environment and its resources (Mikłaszewski, 2000, p. 40).

The concept of eco-development contains the need to change the orientation of the world's economic development strategy. These issues have been raised in the subsequent reports of the Club of Rome. The subject matter of their deliberations was as follows: How resources should be managed in order to ensure the effective improvement of living conditions for all people. What appears in this context is a problem requiring an urgent solution; it is social imbalance in access to resources, which is related to their ownership status, i.e. property (Mikłaszewski, 2000, p. 41).

Eco-development is to facilitate organisations' (enterprises') functioning in the changeable environment. The shaping of the concept of eco-development is to start from raising man's awareness (awareness of eco-developmental issues - Leśniewski, 2013, p. 134). "Eco-developmental awareness concerns man's perception of relationships and integrity among the following three systems: the economy, society and natural environment" (Leśniewski, 2013, p. 134; Leśniewski, 2016b, pp. 151164). One of the foundations for the shaping of eco-development by man (employee) in an organisation is personal or individual culture and organisational culture. 


\section{An organisational culture in the development of a business enterprise}

The literature on the subject proposes a number of definitions or organisational culture (Stańczyk, 2008), also referred to as corporate culture. Schein defines organisational culture as a model of basic principles thought out, discovered or developed by a particular group in the process of learning and specifying the methods of dealing with problems of external adaptation and internal integration (McKenna \& Beech, 1999, p. 35). If such a model functions well, it is considered as the binding one; therefore, new members assimilate it as a correct way of perceiving and thinking or feeling about such problems. A culture is deeply rooted in an organisation; it is some kind of its style, atmosphere, character, specificity of acting (Ożarek, 2001, pp. 23-31). It may be manifested externally in a system of standards and values, work processes, ways of communication, and management practices. Simplifying, one could assume that it is a set of customarily adopted standards of conduct, traditions, and employees' treatment of one another within an organisation.

The shaping of an organisational culture consists in deliberately modifying values, standards and resultant models which should result in new, coherent and more effective configurations of an organisational culture in particular conditions (Sułkowski, 2001, pp. 99-110; Sułkowski, 2012). An organisational culture needs to be deliberately developed because it establishes a framework for behaviours and determines decisions made by all members of an organisation, and thus conditions its effectiveness (Gwiazda, 2002, pp. 20-31). The need to shape an organisational culture is supported additionally by the following circumstances (Kamiński, 2000, p. 8):

- a culture's influence on people's efficiency,

- a culture's influence on employees' motivation and commitment,

- interactions between a culture and normative control of organisational behaviours,

- joint influence of a culture and an organisation's other subsystems,

- occurrence of modifications of values, standards and cultural models in accordance with managers' assumptions.

Among the techniques which may be used to shape, consolidate, correct, develop or change a culture, we can distinguish the following (Sułkowski, 2001, p. 101):

- redefinition of organisational values,

- creation of new normative rules,

- changes in elements of a culture (myths, stories, heroes, models, rituals, symbolism, taboo, language),

- adaptation of artefacts to the changing core of values,

- composition and decomposition of missions,

- designing of communication and power systems,

- changes in the content of job descriptions, 
- meetings, discussions and training sessions for employees,

- shaping of leadership roles in an organisation (e.g. as agents of change, personal models, heroes, innovators),

- shaping of motivational systems,

- changes in selection criteria.

An organisational culture allows a smooth and continuous performance of a collective effort aimed at an organisation's improvement. It helps to create conditions of organisational foundations for the continuous increase in the level of management systems. Employees' awareness of the strength of their organisational culture creates strong foundations for the statement that the current and future condition of their enterprise depends on the effects of work. The future of business management depends on the development of an organisational culture which constitutes a base for an organisation's identity, a determinant of its success, a source of its development, and a building material for its image among customers. In order to maintain a positive organisational culture for a long time, there has to exist an organisational management policy established by a strong leader whose conduct is always irreproachable and deserving of respect. In the next step, it is necessary to establish a solid system of education and training supporting the achievement of the objectives of the management policy; then all members of an organisation will be able to practice the most important concepts and principles in their everyday activities (Tsutsumi \& Tsuchihashi, 2001, pp. 10-14). This will surely lead to excellence in management and perfect business results. Hence the conclusion that in order to perform an effective transformation, one first has to understand a particular enterprise's culture. If the proposed changes will be, for example, contrary to the enterprise's tradition, their implementation will most probably generate minimal effects.

An organisational culture influences an enterprise's success and furthermore, such influence is foreseeable (Zarębska, 2002, p. 12). It is foreseeable particularly when cultural changes are of an evolutionary nature. The strategy of cultural incrementalism is compatible with the gradual introduction of changes in an enterprise (Zarębska, 2002, p. 12).

An organisational culture is a guidebook for acceptable models of behaviour and a determinant of norms and standards; therefore, it plays the role of a significant factor in human resource management - it can be a power supporting or preventing the development of knowledge in an organisation. Business managers should concentrate on the development of such organisational cultures which support internal entrepreneurship, adopt a creative approach to new problems, accept failures and errors in the implementation of innovative solutions, and support information sharing and internal communication. The practices of business enterprises resulting from their organisational cultures are their property and source of competitive advantage. The effectiveness of an organisational culture depends on a degree to which it is shared by the members of a particular organisation. The more difficult it is, the greater the change in an organisational culture is and the more groups lose their privileged positions. 


\section{Eco-developmental competitiveness ${ }^{3}$}

For an organisation (enterprise), eco-developmental competitiveness is a challenge in the area of natural environment protection. It constitutes a starting point at which an enterprise "shakes hands" with the natural environment. It needs to be emphasised that each organisation functions in the natural environment and creates particular relationships with it. ${ }^{4}$ Eco-developmental competitiveness ${ }^{5}$ organises not only relationships between an enterprise and the natural environment but also gives its particular resources a pro-environmental character. Such competitiveness is one of the achievements of the resource-based view in strategic management. The literature on the subject contains a number of notions related to eco-developmental competitiveness such as: sustainable competitiveness of enterprises (AdamkiewiczDrwiłło \& Kruk, 2010, pp. 16-24), ecological competitiveness (Adamkiewicz-Drwiłło \& Kruk, 2008, pp. 141-148), natural competitiveness of regions (Kruk, 2010). Each of these definitions emphasises the importance of the natural environment in the development of an organisation. It is possible to notice that issues related to eco-development evolve from the level of territorial units (regions) towards business entities (enterprises), while the problem of competitiveness, which used to be related mainly to business entities, concerns also territorial units of various levels of a taxonomic division in a particular country. ${ }^{6}$ Figure 1 presents the author's original model of the eco-developmental competitiveness of business enterprises.

The model of the eco-developmental competitiveness of business enterprises consists of soft factors (Bugdol, 2010) and hard factors of competitiveness which supplement each other and constitute a coherent whole. The soft factors include employees' quality, ${ }^{7}$ employees' ecological awareness, employees' eco-developmental awareness, eco-developmental organisational culture, ${ }^{8}$ eco-services, ${ }^{9}$ while hard

3 A part of this analysis comes from: Leśniewski, 2016a, pp. 11-13.

4 Such relationships can be either positive or negative. Positive relationships have a proenvironmental character (e.g. ecological products/services), while negative relationships have an antienvironmental character (e.g. anti-ecological products/services).

5 Leśniewski was the first researcher to define and publish this notion (2013). In that book, eco-developmental competitiveness was defined in the context of communes, i.e. local government units; while the first application of this notion in the context of business enterprises occurred in Leśniewski, 2016a, pp. 3-16.

6 The author of this article has considerable experience resulting from his simultaneous interest in communes and business enterprises (a commune as an analogue of a business enterprise). The author's research interests are dominated by the issue of competitiveness in relation to various aspects of the development of enterprises, including eco-development.

7 The number of employees is regarded as one of the hard factors of competitiveness.

8 More on the soft factors of competitiveness in Leśniewski, 2015a.

9 Eco-services are a soft factor of competitiveness because what counts in eco-services is the quality of performed services, and not their quantity. Quality as usefulness or the customer's satisfaction constitutes a soft factor of competitiveness. 


\begin{tabular}{|}
\begin{tabular}{|c|c|c|c|}
\hline $\begin{array}{c}\text { Quality and number of } \\
\text { employees } \\
\text { (human resources) }\end{array}$ & $\begin{array}{c}\text { Employees' ecological } \\
\text { awareness }\end{array}$ & $\begin{array}{c}\text { Employees' } \\
\text { eco-developmental } \\
\text { awareness }\end{array}$ & $\begin{array}{c}\text { Eco-developmental } \\
\text { organisational culture }\end{array}$ \\
\hline \multicolumn{4}{|c|}{ Eco-developmental competitiveness of business enterprises } \\
\hline $\begin{array}{c}\text { Eco-developmental } \\
\text { location of business } \\
\text { enterprises }\end{array}$ & Eco-technologies & Eco-production & $\begin{array}{c}\text { Eco-products/ } \\
\text { eco-services }\end{array}$ \\
\hline
\end{tabular}
\end{tabular}

Legend:

- Quality and quantity of employees (human resources) - the quality of employees understood as: willingness to get involved in work, an attitude towards work, motivation to work, creating positive interpersonal relationships, holding qualifications adequate for held positions (being a professional employee); number of employees - the total number of people employed in an organisation (headcount),

- Employees' ecological awareness - employees' ability to perceive a single-system relationship between their organisation and the natural environment,

- Employees' eco-developmental awareness - employees' ability to perceive a triple-system relationship among their organisation, society, and the natural environment. Ecological awareness constitutes a basis for eco-developmental awareness,

- Eco-developmental organisational culture - a type (profile) of culture in which eco-development is the supreme and constitutive value,

- Eco-developmental location of business enterprises - a type of location (positioning) favourable for an organisation's pursuit of eco-development,

- Eco-technologies - types of technologies friendly for the natural environment; compatibility of technologies with the natural environment (so-called clean or green technologies),

- Eco-production - a production line whose operation in a business enterprise does not constitute a threat to the natural environment,

- Eco-products/eco-services - products/services whose consumption does not constitute a threat to the natural environment. The manufacture of eco-products or the provision of eco-services requires the application of eco-technologies and eco-production.

Figure 1. A model of the eco-developmental competitiveness of business enterprises. ${ }^{10}$

Source: based on Leśniewski, 2015b, Leśniewski, 2016a, p. 12.

factors comprise the number of employees, the eco-developmental location of business enterprises, eco-technologies, eco-production, and eco-products. It should be noted that the process of making decisions (Budzanowska-Drzewiecka, 2011, pp. 443-455) with respect to any factor of competitiveness in the presented model

10 This model has been developed on the basis of a research survey conducted by the author of this article and interpretation of its results. 
has a soft character. ${ }^{11}$ Effectiveness in the implementation of the eco-developmental competitiveness model depends, among other things, on positive relationships ${ }^{12}$ among the particular factors and the way of implementing ${ }^{13}$ the factors of eco-developmental competitiveness in a business enterprise (organisation).

Eco-developmental competitiveness entails the management's perception of relationships between soft factors and hard factors contributing to the shaping of business enterprises' eco-developmental potential. It is necessary to combine skilfully these elements which will be moving a business entity closer and closer to the state of eco-developmental competitiveness. The starting point for implementing and shaping this form of competitiveness in a business enterprise is the employment and retention of employees who demonstrate ecological awareness and eco-developmental awareness (Leśniewski, 2016b, pp. 151-164). These soft factors will be responsible for the other factors which will be shaping eco-developmental competitiveness. One could venture an opinion that ecological awareness and eco-developmental awareness are primary factors, while the remaining factors of eco-developmental competitiveness are of a secondary character (Leśniewski, 2016a, p. 13).

\section{Research methodology}

The research constituting a basis for the proposed model approaches was conducted in the years 2010-2015 on a research sample of 200 microenterprises representing various business sectors in the Świętokrzyskie Province. The enterprises were based in the city of Kielce and the Kielecki District as well as other administrative districts of the Świętokrzyskie Province. The respondents of the research survey were the owners of the microenterprises.

The research was based on the survey method with a questionnaire containing open questions. In the research, stress was put on the respondents' freedom in providing answers to the questions because the eco-developmental organisa-

11 Broadly understood decision making is classified as an element of soft management. Decision making has a subjective character because it depends on a particular person, e.g. one manager in a particular matter opts for a "no" decision, while another chooses a "yes" decision; sometimes managers make decisions which are mutually exclusive. Sometimes a decision-making process can be characterised by a dichotomy of managerial thinking.

12 Positive relationships are mutual relationships among factors contributing to the appreciation of an organisation's value. Their opposite is negative relationships which contribute to the generation of pathological situations, including conflicts, and may eventually cause depreciation of an organisation's value. The initiator of relationships is a manager holding a particular place in both the organisational structure and the decision-making structure.

13 The methods of implementing eco-development in a business enterprise may be based on soft factors, hard factors or mixed hard and soft factors. 
tional culture is a new issue analysed within a scientific context. Providing free answers, the respondents had an opportunity to create a structure of an eco-developmental organisational culture (answering freely, respondents are more open and active).

Having provided a free answer, each respondent estimated its intensity (certainty that the answer was correct), using a five-degree Likert scale, i.e. 1 - I definitely disagree, 2 - I rather disagree, 3 - I have no opinion, 4 - I rather agree, 5 - I definitely agree.

The analysed elements of the eco-developmental organisational culture (ecodevelopmental culture) of business enterprises are indications whose intensity was estimated at 4 or 5 on the Likert scale.

The collected data was analysed by means of the Statistica software.

\section{The eco-developmental organisational culture (eco-developmental culture) of business enterprises - research results}

An eco-developmental organisational culture (eco-developmental culture) is a detailed specialist form (profile) of an organisational culture allowing a business enterprise (organisation) to follow "the path of eco-development" for the benefit of the organisation and the environment in which it functions. This type of culture is created by an eco-developmental enterprise. Each organisational culture, including an eco-developmental organisational culture (eco-developmental culture) is shaped by these elements which determine its significance for a business enterprise. Table 1 presents the elements of the eco-developmental organisational culture (eco-developmental culture) of business enterprises.

The elements in Table 1 are divided (from the qualitative point of view) into two qualitative groups of factors, i.e. soft factors ${ }^{14}$ and hard factors. ${ }^{15}$ The following elements are classified as soft factors: knowledge of the notion of eco-development (12.25\%), possession of ecological awareness (10.15\%), possession of eco-developmental awareness (11.17\%), eco-development deeply rooted in employees' awareness (13.14\%), training of employees in ecology and eco-development (7.09\%), change of the organisation towards ecology and eco-development (5.07\%), open-

14 Soft factors are factors characterised by flexibility (softness) in their structures or functioning. Examples of soft factors include awareness, training, knowledge (knowledge sharing), etc.

15 Hard factors are factors deprived of flexibility (the lack of flexibility, or hardness) in their structures or functioning. Examples of hard factors include legal regulations, strategies, an organisational structure, financial resources (money), etc. The qualitative groups of factors consist of both soft and hard factors. The borderline between a soft factor and a hard factor is noticeable; however, the same does not apply to the border between soft factors only. 
Table 1 The elements of the eco-developmental organisational culture (eco-developmental culture) of business enterprises - the soft and hard factors, $N=200$

\begin{tabular}{|l|r|r|}
\hline $\begin{array}{l}\text { The elements of the eco-developmental organisational culture (eco- } \\
\text { developmental culture) of business enterprises }\end{array}$ & $\begin{array}{l}\text { Percentage of } \\
\text { answers }\end{array}$ & $\begin{array}{r}\text { Number of } \\
\text { indications }\end{array}$ \\
\hline Knowledge of the notion of eco-development - soft factor & 12.25 & 24.50 \\
\hline Possession of ecological awareness - soft factor & 10.15 & 20.30 \\
\hline Possession of eco-developmental awareness - soft factor & 11.17 & 22.34 \\
\hline Eco-development deeply rooted in employees' awareness - soft factor & 6.04 & 26.28 \\
\hline Compliance with environmental protection regulations - hard factor & 7.09 & 12.08 \\
\hline Training of employees in ecology and eco-development - soft factor & 5.07 & 10.14 \\
\hline $\begin{array}{l}\text { Change of the organisation towards ecology and eco-development - } \\
\text { soft factor }\end{array}$ & 5.00 \\
\hline $\begin{array}{l}\text { Openness to other changes contributing to the shaping of eco-develop- } \\
\text { ment in the organisation - soft factor }\end{array}$ & 15.04 & 10.00 \\
\hline $\begin{array}{l}\text { Permeation of eco-development through the organisational structure } \\
\text { - soft factor }\end{array}$ & 15.05 & 30.08 \\
\hline $\begin{array}{l}\text { Permanent profiling of the organisational culture towards eco-devel- } \\
\text { opment (eco-developmental organisational culture, eco-developmental } \\
\text { culture) - soft factor }\end{array}$ & & 30.01 \\
\hline
\end{tabular}

Legend (interpretation of the elements' meanings):

- knowledge of the notion of eco-development - the status of employees' knowledge of eco-development,

- possession of ecological awareness - employees' ability to perceive a single-system relationship between their organisation and the natural environment,

- possession of eco-developmental awareness - employees' ability to perceive a triple-system relationship among their organisation, society, and the natural environment. Ecological awareness constitutes a basis for eco-developmental awareness,

- eco-development deeply rooted in employees' awareness - strengthening the awareness of all ecodevelopmental activities thanks to which employees will perform such activities as a natural consequence of their functioning in the organisation (e.g. employees do not have to be told to segregate litter; they know that it has to be done and they do it, etc.),

- compliance with environmental protection regulations - taking into consideration all environmental protection regulations in the organisation's development,

- training of employees in ecology and eco-development - providing employees with direct and indirect knowledge of ecology and eco-development. Direct knowledge can be exemplified by the protection of the natural environment, the rudiments of ecology or eco-development. Indirect knowledge can be exemplified by knowledge the background of which is oriented toward ecology or eco-development (e.g. motivation systems in the organisation of eco-development),

- change of the organisation towards ecology and eco-development - all changes aiming directly at ecology and eco-development,

- openness to other changes contributing to the shaping of eco-development in the organisation employees' friendly approach or attitude towards these changes that contribute directly to the organisation's eco-development,

- permeation of eco-development through the organisational structure - the effect of saturating the organisation with eco-development, i.e. each organisational unit in the organisational structure is able to implement eco-development in its operational profile,

- permanent profiling of the organisational culture towards eco-development (eco-developmental organisational culture, eco-developmental culture) - the continuous monitoring of the culturecreating factors related to the organisational culture.

Source: based on Leśniewski, 2015b. 
ness to other changes contributing to the shaping of eco-development in the organisation $(5.00 \%)$, permeation of eco-development through the organisational structure (15.04\%), permanent profiling of the organisational culture towards eco-development (eco-developmental organisational culture, eco-developmental culture) $(15.05 \%)$, while compliance with environmental protection regulations (6.04\%) is considered as a hard factor.

The collected data indicate that the eco-developmental organisational culture (eco-developmental culture) of the surveyed enterprises is dominated by two socalled qualitative groups of factors, i.e. soft factors constituting a decisive majority of the eco-culture-creating factors; ${ }^{16}$ hard factors constitute a decisive minority of these factors (in this case, it is just one hard factor).

Analysing the data presented in Table 1, it is possible to notice the occurrence of the so-called quantitative fragmentation of the eco-culture creating factors, i.e. in this case, the elements of the eco-developmental organisational culture of business enterprises.

The surveyed business entities point out that the shaping of this type of an organisational culture profile is based on a few/a dozen or so factors. On the basis of the percentage distribution of the answers, it is possible to distinguish two groups of factors, so-called threshold groups. One of them includes these factors that have achieved $10 \%$ or more indications. The other threshold group comprises these factors that have scored less than $10 \%$ of the answers. The interpretation of the elements of the factors in Table 1 should be based on the systemic approach and the complementary approach, i.e. all factors create among themselves a system of ecoculture-creating factors included simultaneously in the system of the whole enterprise and all factors supplement (support) each other.

The division into the qualitative groups of factors and quantitative groups of factors emphasises the fact of the mutual interlacing of quality and quantity as well as the fact that each factor contributes eventually to the value of the development of an organisation (business enterprise).

16 Eco-culture-creating factors - factors contributing to the shaping of an organisational culture which is friendly to the natural environment. This type of culture can be exemplified by the eco-developmental organisational culture. Examples of eco-culture-creating factors include waste segregation, ecological awareness and eco-developmental awareness, openness to other changes contributing to the shaping of eco-development in an organisation, etc. Each factor contributing to the shaping of eco-development in an organisation will be classified as an ecoculture-creating factor. The prefix eco- in the term eco-culture-creating comes from ecology and eco-development. 


\section{A model of the eco-developmental organisational culture in the eco-developmental competitiveness of business enterprises}

Organisational culture and competitiveness constitute two inseparable components of the development of an organisation (business enterprise). They can be approached in an either general or particular way. A particular approach to organisational culture and competitiveness can be exemplified by an eco-developmental organisational culture and eco-developmental competitiveness. Such a culture and competitiveness are presented within the economic realities, where they adopt the form of an eco-developmental organisational culture of enterprises and eco-developmental competitiveness of enterprises. ${ }^{17}$ Both these issues constitute important links in the chain of the eco-developmental enterprise. ${ }^{18}$ Figure 2 presents the author's original model of the eco-developmental organisational culture in the eco-developmental competitiveness of business enterprises - the Model of the Eco-developmental Cultural Competitiveness of Business Enterprises (the ECCB Model).

The model illustrated in Figure 2 presents the factors creating the eco-developmental organisational culture as well as the factors of the eco-developmental competitiveness of business enterprises. Both the former and the latter are mutually complementary. They create a comprehensive system of an enterprise's cultural competitiveness in which an organisational culture "melts into" its competitiveness. The combination of the eco-developmental organisational culture and eco-developmental competitiveness results in the eco-developmental cultural competitiveness of business enterprises. An eco-developmental organisational culture has its own factor-related structure and at the same time is a factor included in the structure of the eco-developmental competitiveness of business enterprises.

Analysing the model presented in Figure 2, one can notice a few common factors creating simultaneously the eco-developmental organisational culture and ecodevelopmental competitiveness of business enterprises. Such common factors within the eco-developmental organisational culture include the following: possession of ecological awareness, possession of eco-developmental awareness and permanent profiling of the organisational culture towards eco-development (eco-developmental organisational culture, eco-developmental culture); in eco-developmental competitiveness, such common factors are the following: employees' ecological awareness, employees' eco-developmental awareness, and eco-developmental organisational culture. The possession of common factors is the expression of the synergistic and

17 The issues of the eco-developmental organisational culture and eco-developmental competitiveness can refer to not only business enterprises but also other organisations such as commune offices, in which case they will be understood as the eco-developmental organisational culture of communes and the eco-developmental competitiveness of communes, etc.

18 It is also possible to use the notion of an eco-developmental enterprise interchangeably. 


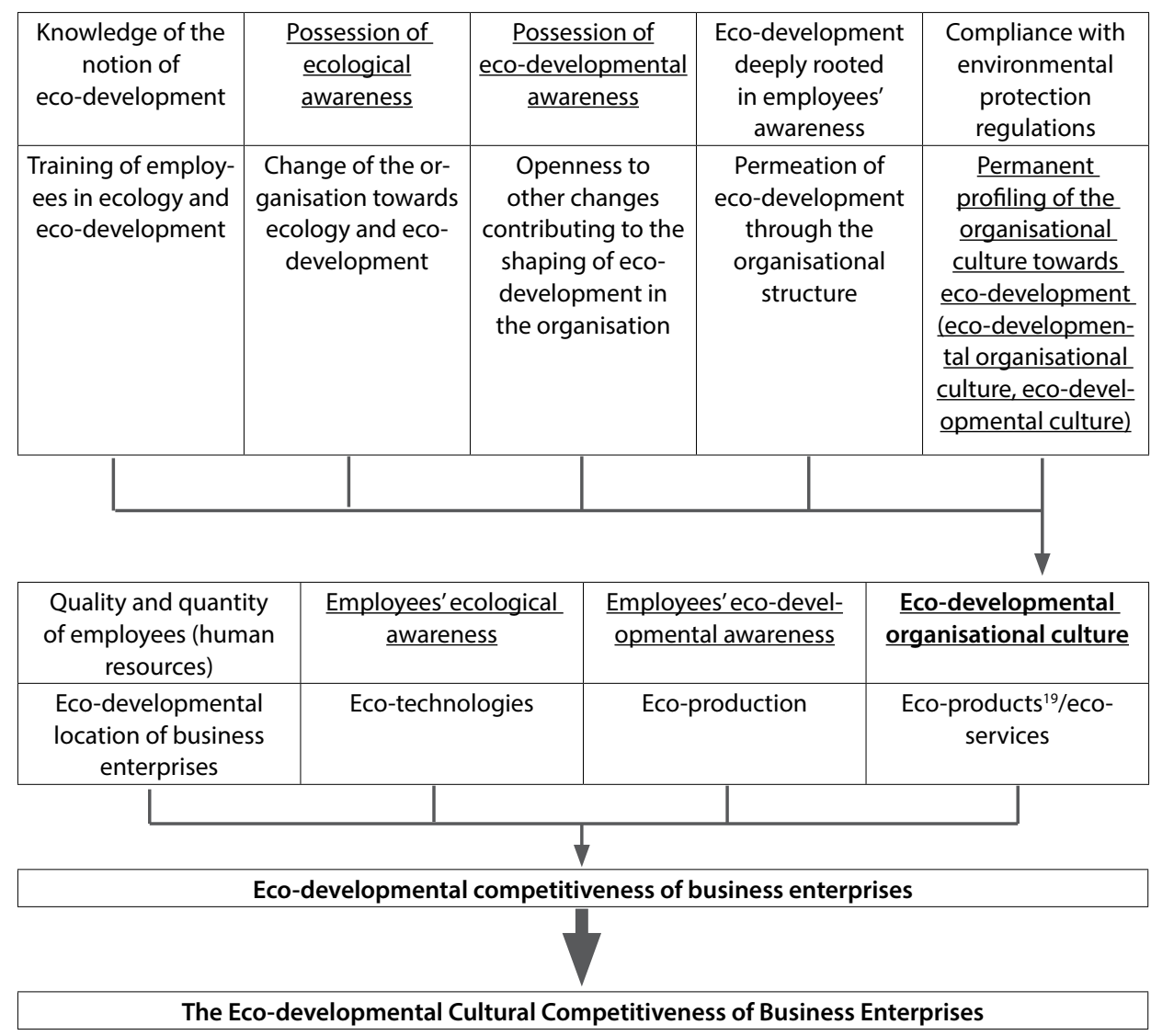

Legend:

The underlined factors, i.e. possession of ecological awareness, possession of eco-developmental awareness, permanent profiling of the organisational culture towards eco-development (eco-developmental organisational culture, eco-developmental culture), employees' ecological awareness, employees' ecodevelopmental awareness, and eco-developmental organisational culture, are common factors for the ecodevelopmental organisational culture and eco-developmental competitiveness of business enterprises.

Figure 2. The model of the eco-developmental organisational culture in the eco-developmental competitiveness of business enterprises - the Model of the Eco-developmental Cultural Competitiveness of Business Enterprises (the ECCB Model) ${ }^{20}$

Source: based on Leśniewski, 2015b, Leśniewski, 2016a, p. 12.

19 Eco-products need to be made of eco-materials. The original form of the eco-developmental competitiveness model does not include the factor of eco-materials. The logic of the analysis of the model has resulted in the generation of this factor, according to the premise that eco-products come from eco-materials.

20 This model has been developed on the basis of a research survey conducted by the author of this article and interpretation of its results. 
complementary functioning of both the eco-developmental organisational culture and eco-developmental competitiveness in the form of the eco-developmental cultural competitiveness of business enterprises. This type of competitiveness is an integral element of the essence of the eco-developmental enterprise. Competitiveness, including eco-developmental cultural competitiveness, has to be under an enterprise's continuous monitoring because once achieved, it does not last forever.

The eco-developmental organisational culture and eco-developmental competitiveness with its reflection in the form of eco-developmental cultural competitiveness constitute a characteristic foundation for the shaping of the eco-developmental enterprise being a reaction to changes in the approach to natural environment protection. One could say that the clean natural environment means the healthy man (employee).

\section{Conclusions}

Man and the natural environment constitute two inseparable and coexistent systems. One of the solutions concerning the creation of positive relationships among man, society, the economy and the natural environment is the "path" of eco-development. Both man and the natural environment are incorporated in various organisations, including business enterprises. This incorporation may manifest itself in various areas of the activities of a business enterprise. One of the examples is the eco-developmental organisational culture and eco-developmental competitiveness, which manifest themselves in the eco-developmental cultural competitiveness of business enterprises. These issues constitute some kind of a base for the shaping of the so-called eco-developmental enterprise.

The conducted research has allowed the creation of a certain picture of the reality of the eco-developmental functioning of a business enterprise in the form of the eco-developmental organisational culture, eco-developmental competitiveness and eco-developmental cultural competitiveness of business enterprises. As a resource, the eco-developmental organisational culture is shaped not only by soft factors but also by hard factors. These factors supplement each other and determine the occurrence of the synergy effect. This culture itself is regarded as a resource, but when it is a component of eco-developmental competitiveness, it is regarded as a factor (the resource and factor approach). The components of the eco-developmental organisational culture shape not only the organisational culture itself but also eco-developmental competitiveness, which consequently contributes to the eco-developmental cultural competitiveness of business enterprises. The presented Model of the Ecodevelopmental Cultural Competitiveness of Business Enterprises constitutes an important component of the eco-developmental enterprise, where respect for the natural environment is the primary value in the development of man (employee) and the whole business entity. What is created in such a case is an eco-developmental and humanistic image of man (Kociatkiewicz \& Kostera, 2013, pp. 9-19). 
The presented research problem is very important for the development of man in an organisation and the development of an organisation itself in the changeable circumstances, particularly when the natural environment is respected and protected. Eco-development constitutes not only an area of enterprises' competitiveness in the form of eco-developmental competitiveness but also an area of an organisational culture in the form of the eco-developmental organisational culture (eco-developmental culture). The combined approach to both of these areas of business enterprises gives a picture of the Eco-developmental Cultural Competitiveness of Enterprises. The presented research results show that, in its structure, the eco-developmental organisational culture possesses various elements most of which have a soft character. Depending on the quality of employees, these elements will undergo changes. Organisations should employ and retain so-called qualitatively eco-developmental employees, i.e. such who, thanks to their commitment, competences, experience and knowledge related to eco-development, will be contributing to the eco-developmental potential of their enterprise. If an enterprise is to maintain its eco-developmental organisational culture in the future, each element of this culture should be strengthened systematically so that it becomes rooted down in the awareness of employees (ecodevelopmental awareness). Employees should always be aware that the eco-developmental organisational culture is compatible with eco-developmental competitiveness, which determines the creation of the Eco-developmental Cultural Competitiveness of Enterprises. This issue constitutes an integrated approach to eco-development, competitiveness, and organisational culture. Possessing the Eco-developmental Cultural Competitiveness of Enterprises, an organisation moves towards the path of ecodevelopment, which results in such an organisation's living in harmony with nature.

\section{References}

Adamkiewicz-Drwiłło, H.G., \& Kruk, H. (2008). Konkurencyjność ekologiczna jako jeden z aspektów strategicznej konkurencyjności przedsiębiorstwa. In Z. Dworzecki, M. Romanowska (eds.), Strategie przedsiębiorstw w otoczeniu globalnym. Warszawa: Oficyna Wydawnicza SGH, pp. 141-148.

Adamkiewicz-Drwiłło, H.G., \& Kruk, H. (2010). Zrównoważona konkurencyjność przedsiębiorstw - ujęcie teoretyczne. Studia i Prace Kolegium Zarządzania i Finansów, (98), 16-24.

Borys, T. (1999). Wskaźniki ekorozwoju. Białystok: Wydawnictwo Ekonomia i Środowisko.

Budzanowska-Drzewiecka, M. (2011). Specyfika procesu podejmowania decyzji o zakupie przez młodych konsumentów. Zeszyty Naukowe Uniwersytetu Szczecińskiego. Ekonomiczne Problemy Usług, (72 Marketing przyszłości: trendy, strategie, instrumenty: zachowania konsumentów - trendy i kierunki zmian), 443-455.

Bugdol, M. (2010). Zaufanie jako element systemu wartości organizacyjnych. Współczesne Zarządzanie, (2), 11-25.

Czyż, M. (2000). Rozwój zrównoważony a przemiany cywilizacyjne. In S. Zięba, M. Wróblewski (eds.), Ekologia a transformacje cywilizacyjne na przełomie wieków. Lublin: UMCS. 
Gwiazda, E. (2002). Badania socjologiczne kultury organizacyjnej. Ekonomika i Organizacja Przedsiębiorstwa, (10), 20-31.

Jedynak, P. (ed.) (2010). Wiedza współczesnych organizacji. Wybrane problemy zarządzania. Kraków: Wydawnictwo Uniwersytetu Jagiellońskiego.

Kamiński, R. (2000). Kultura organizacyjna a sprawność organizacji. Ekonomika i Organizacja Przedsiębiorstwa, (9), 6-10.

Kociatkiewicz, J., \& Kostera, M. (2013). Zarządzanie humanistyczne. Zarys programu. Problemy Zarzadzania, (4), 9-19.

Kołodziejski, J. (1997). Strategia równoważenia rozwoju podstawą koncepcji polityki przestrzennego zagospodarowania kraju „Polska 2000 Plus”. In J. Kołodziejski (ed.), Polska przestrzeń a wyzwania XXI wieku. Biuletyn KPZK, (176). Warszawa: Wydawnictwo Naukowe PWN, pp. 49-50.

Kozak, M.A., Pyszkowski, R., \& Szewczyk, R. (2001). Słownik rozwoju regionalnego. Warszawa: PARR.

Kozłowski, S. (1998). Ogólne uwarunkowania ekorozwoju. In B. Poskrobko (ed.), Sterowanie ekorozwojem. Teoretyczne aspekty ekorozwoju (vol. I). Białystok: Politechnika Białostocka.

Kruk, H. (2010). Przyrodnicza konkurencyjność regionów. Toruń: Dom Organizatora TNOiK.

Leśniewski, M.A. (2013). Ekorozwojowe źródła konkurencyjności gmin w Polsce. Warszawa: CeDeWu.

Leśniewski, M.A. (2015a). Konkurencyjność miękka przedsiębiorstw. Warszawa: Difin.

Leśniewski, M.A. (2015b). Konkurencyjność ekorozwojowa, świadomość ekorozwojowa oraz ekorozwojowa kultura organizacyjna czynnikami ksztattowania ekorozwojowego przedsiębiorstwa na przykładzie podmiotów gospodarczych regionu świętokrzyskiego. Badania własne. Kielce: Uniwersytet Jana Kochanowskiego.

Leśniewski, M.A. (2016a). Konkurencyjność ekorozwojowa przedsiębiorstw. Ekonomika i Organizacja Przedsiębiorstwa, (3), 11-13.

Leśniewski, M.A. (2016b). Świadomość ekorozwojowa w konkurencyjności miękkiej przedsiębiorstw. Edukacja Ekonomistów i Menedżerów, (2), 151-164.

Lipińska, A. (2015). Knowledge management in a virtual organization. Jagiellonian Journal of Management, 1(1), 65-76.

McKenna, E., \& Beech, N. (1999). Zarządzanie zasobami ludzkimi. Warszawa: Wydawnictwo Felberg SJA.

Mikłaszewski, A. (2000). Ekorozwój - rozwój zrównoważony. Prace Naukowe Instytutu Górnictwa Politechniki Wrocławskiej, (87), 39-46.

Nowicki, M., \& Ribbe, L. (2001). Problemy ekorozwoju Polski. Warszawa: Agencja ReklamowoWydawnicza.

Ożarek, G. (2001). Jakość wyrobów i usług jako zagadnienie etyczne: aspekty techniczne i ekonomiczne. Problemy Jakości, (11), 23-31.

Pęski, W. (1999). Zarządzanie zrównoważonym rozwojem miast. Warszawa: Arkady.

Stańczyk, S. (2008). Nurt kulturowy w zarządzaniu. Wrocław: Uniwersytet Ekonomiczny we Wrocławiu.

Sułkowski, Ł. (2001). Czy jest możliwe kształtowanie kultury organizacyjnej? Organizacja i Kierowanie, (4), 99-110.

Sułkowski, Ł. (2012). Kulturowe procesy zarządzania. Warszawa: Difin.

Tsutsumi, S., \& Tsuchihashi, K. (2001). Przez TQM do doskonałości w zarządzaniu. Problemy Jakości, (12), 10-14.

Zarębska, A. (2002). Kultura przedsiębiorstwa w procesie zmian organizacyjnych. Przegląd Organizacji, (6), 11-13. 
Note about the Author

Michae A. Leśniewski, Ph.D. - is a doctor of economic sciences in the field of management. He works at the Department of Management, the University of Jan Kochanowski in Kielce. His current research interests include soft management issues, soft competitiveness, cultural competitiveness, organizational culture and positive potential of organisations. He collaborates with such scientific journals as Ekonomika i Organizacja Przedsiębiorstwa and Przeglad Organizacji. He is the author of the monograph entitled Konkurencyjnośc miękka przedsiębiorstw (Soft Competitiveness of Enterprises) (2015), Warszawa: Difin. 